\title{
Prenatal diagnosis of tetralogy of Fallot with a restrictive ventricular septal defect
}

\author{
Cecilia Villalaín ${ }^{1}$ (D) , David Escribano (D) , Enery Gómez-Montes ${ }^{1}$ (D) , Miguel Ángel Granados² (D), \\ Enrique García ${ }^{2}$, Alberto Galindo (iD \\ ${ }^{1}$ Fetal Medicine Unit - Maternal and Child Health and Development Network, Hospital Universitario 12 de Octubre, Madrid, Spain \\ ${ }^{2}$ Department of Pediatrics, Pediatric Heart Institute, Hospital Universitario 12 de Octubre, Madrid, Spain
}

\begin{abstract}
Objective: Tetralogy of Fallot (TOF) usually presents with a large non-restrictive ventricular septal defect (VSD).

Case: We hereby report a rare case of prenatal diagnosis of TOF with a restrictive VSD secondary to redundant tricuspid valve tissue. Partial occlusion of the VSD resulted in prenatal progression to myocardial hypertrophy and postnatally to right heart failure with difficult management.

Conclusion: Prenatal signs of cardiac dysfunction in TOF should prompt a detailed exam of the VSD. Parents and neonatologists must be advised and delivery must be guaranteed in a tertiary center.
\end{abstract}

Keywords: Tetralogy of Fallot, restrictive, ventricular septal defect.

\section{Introduction}

Tetralogy of Fallot (TOF) usually presents with a large non-restrictive ventricular septal defect (VSD). It has been described postnatally that in rare cases, the VSD can become restrictive and prompt cardiac failure. ${ }^{[1]}$ We hereby present a rare case of prenatal diagnosis of TOF with a restrictive perimembranous VSD.

\section{Case Report}

A 20-week primigravida case was referred for suspicion of congenital heart defect. The exam at our Fetal Medicine Unit confirmed diagnosis of TOF with

\section{Özet: Fallot tetralojisinin restriktif ventriküler septal defekt ile prenatal tanısı}

Amaç: Fallot tetralojisi (FT) genellikle büyük non-restriktif ventriküler septal defekt ile seyretmektedir.

Olgu: Bu çalışmada, kalıntı triküspit kapak dokusuna sekonder restriktif VSD ile prenatal FT tanısının nadir bir olgusunu sunmaktayız. VSD'nin kısmi oklüzyonu, miyokardiyal hipertrofinin prenatal ilerleyişi ve postnatal olarak güç yönetime sahip sağ kalp yetmezliği ile sonuçlanmıştır.

Sonuç: FT'de kardiyak disfonksiyonun prenatal belirtileri halinde detaylı VSD muayenesi düşünülmelidir. Ebeveynlere ve neonatologlara danışmanlık verilmelidir ve doğum tersiyer bir merkezde güvenceye alınmalıdır.

Anahtar sözcükler: Fallot tetralojisi, restriktif, ventriküler septal defekt.

severe pulmonary stenosis. An additional orofacial cleft was found and array-CGH showed no pathological findings. After parental counselling, follow-up scans were performed monthly. At 34 weeks the fetus developed a symmetrical cardiomegaly with myocardial hypertrophy and no additional signs of cardiac dysfunction. Tricuspid valve was competent but an echogenic $7 \mathrm{~mm}$ subvalvular thickening partially occluded the VSD during diastole resulting in a restrictive VSD (peak flow $217 \mathrm{~cm} / \mathrm{s}$ ) (Fig. 1). A follow-up scan was scheduled in $72 \mathrm{~h}$. However, the mother was admitted two days later for premature rupture of membranes and labor was induced after fetal matura-

\footnotetext{
Correspondence: Cecilia Villalaín, MD. Fetal Medicine Unit - Maternal and Child Health and Development Network, Hospital Universitario 12 de Octubre, Madrid, Spain. e-mail: cecilia.villalain@salud.madrid.org / Received: January 18, 2021; Accepted: February 11, 2021

How to cite this article: Villalaín C, Escribano D, Gómez-Montes E, Granados MÁ, García E, Galindo A. Prenatal diagnosis of tetralogy of Fallot with a restrictive ventricular septal defect. Perinatal Journal 2021;29(1):83-86. doi:10.2399/prn.21.0291013
}

ORCID ID: C. Villalaín 0000-0002-9456-4100; D. Escribano 0000-0002-2526-1771; E. Gómez-Montes 0000-0003-2099-1633; 

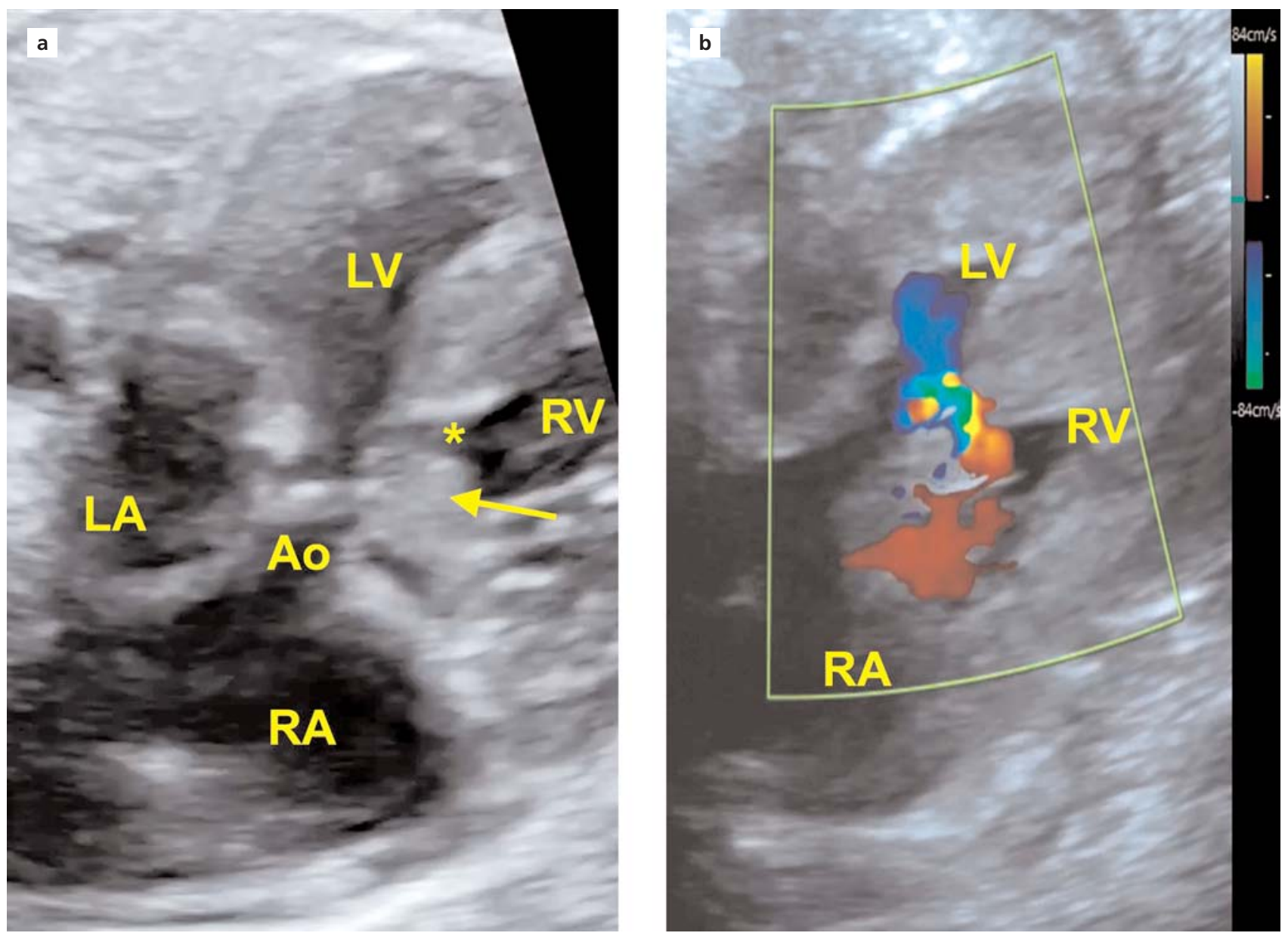

Fig. 1. Prenatal ultrasound. (a) A left ventricle outflow tract with a ventricular septal defect (*) and the redundant tricuspid valve (marked by an arrow) in B mode. (b) Color Doppler flow through the ventricular septal defect in the four chamber view. LA: left atrium; LV: left ventricle; RA: right atrium; RV: right ventricle.

tion. The diagnosis was confirmed postnatally (Fig. 2). The neonate was initially managed with PGE1 infusion and placement of a ductal stent in the first week. Difficulty in hemodynamic management urged a semicorrective surgery with transannular patch and closure of the arterial duct 2 months later. Subsequent clinical instability required corrective surgery at 3 months, with resection of the accessory tricuspid valve tissue, modelling of the right outflow tract and closure of the VSD. The patient is now extubated, stable with adequate ventricular function, awaiting cleft palate surgery.

\section{Discussion}

TOF usually presents with a large non-restrictive VSD. In rare cases of TOF, inter-ventricular flow can be obstructed by accessory tricuspid valve tissue, a prolapsed aortic valve or fibrous tissue originated from the membranous hypertrophied ventricular septum, being the first one the most common etiology. ${ }^{[2]}$ This flow restriction can cause suprasystemic right ventricular pressure and subsequent right heart failure. ${ }^{[3]}$ Accessory tricuspid valve tissue is thought to arise from continuous ventricular pressure due to a prolonged exposure to critical pulmonary stenosis or pulmonary atresia and results in an obstruction of the VSD. Faggian et al. have described two types of accessory tissue according to its mobility: mobile and fixed. ${ }^{[4]}$ The first one, as in our case, can be identified as a parachute-like leaflet floating in the ventricular outflow tract, and may protrude into the sub-aortic region causing ventricular 

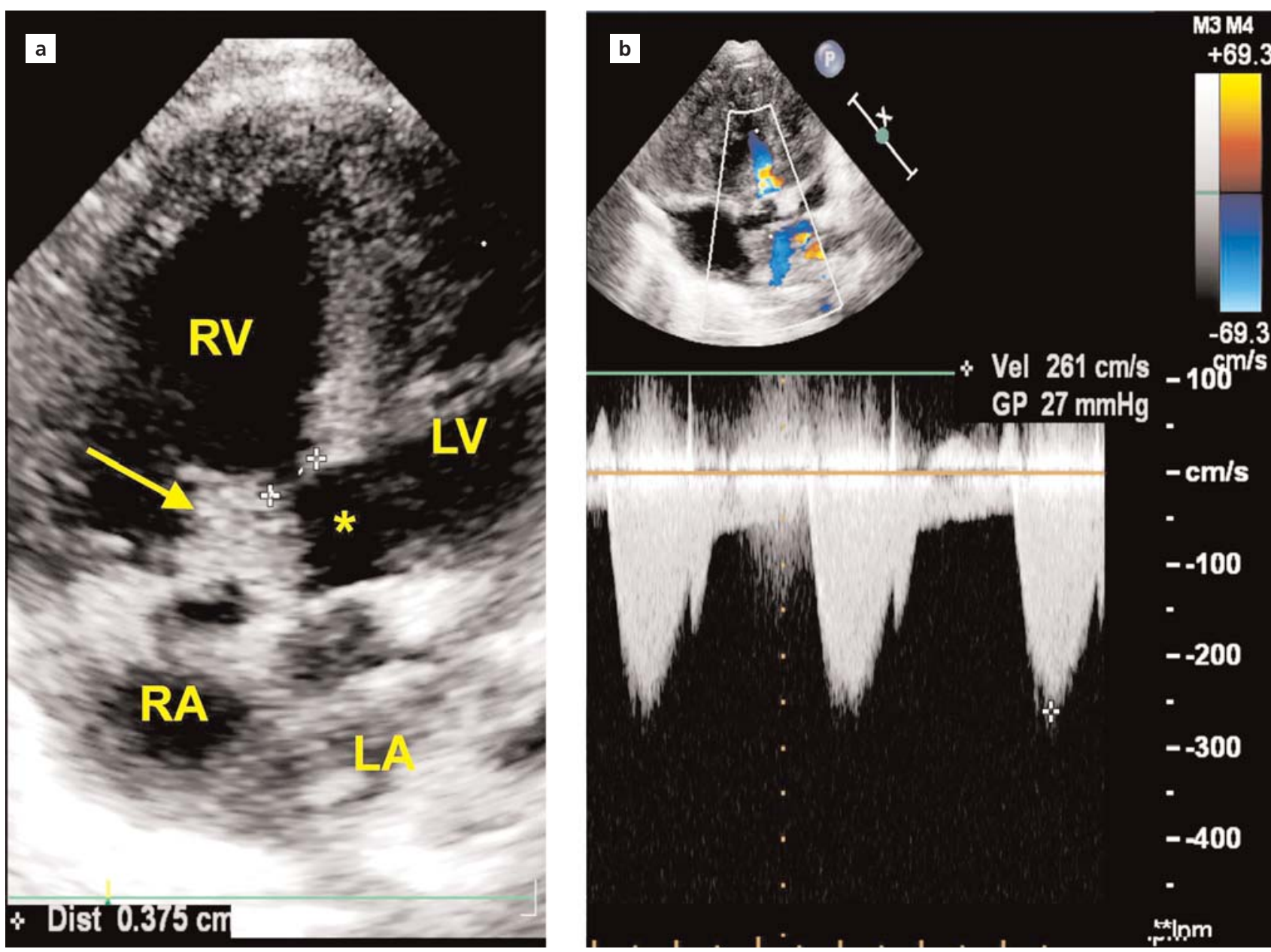

Fig. 2. Postnatal ultrasound. (a) A five chamber view with the ventricular septal defect $\left(^{*}\right.$ ) and the redundant tricuspid valve (marked by an arrow) in B mode. (b) Color Doppler flow through the ventricular septal defect in the five chamber view. LA: left atrium; LV: left ventricle; RA: right atrium; RV: right ventricle.

outflow obstruction. To the best of our knowledge, these findings have only been identified postnatally, with an estimated incidence of $1.4 \%$ and is thought to increase surgical mortality as well as be one of the causes of cardiac congestive heart failure in TOF ${ }^{[1]}$ requiring early surgery to avoid right ventricular failure. Preoperative knowledge of this lesion is expected to reduce surgical mortality. ${ }^{[5]}$

\section{Conclusion}

TOF can be a progressive disease and therefore warrants periodic follow-up. Prenatal signs of cardiac dysfunction in TOF should prompt a detailed exam of the VSD in order to detect and characterize a restriction to the flow as a possible underlying cause for cardiac dysfunction. Parents and neonatologists must be alerted and delivery must be guaranteed in a tertiary center since cardiac dysfunction can be severe, difficult to manage and require different surgeries to those usually scheduled.

Funding: This work did not receive any specific grant from funding agencies in the public, commercial, or not-for-profit sectors.

Compliance with Ethical Standards: The authors stated that the standards regarding research and publication ethics, the Personal Data Protection Law and the copyright regulations applicable to intellectual and artistic works are complied with and there is no conflict of interest. 


\section{References}

1. Tiwari A, Bhunwal S, Rohit M. Tetralogy of Fallot with restrictive ventricular septal defect. Indian J Pediatr 2018;85: 400. [PubMed] [CrossRef]

2. Flanagan MF, Foran RB, VanPraagh R, Jonas R, Sanders SP. Tetralogy of Fallot with obstruction of the ventricular septal defect: spectrum of echocardiographic findings. J Am Coll Cardiol 1998;11:386-95. [PubMed] [CrossRef]

3. Kumar PR, Rakshak AD, Rajagopal P, Padmanabhan TN, Rao DS, Jaishanker S. Tetralogy of Fallot with flap valve ven- tricular septal defect producing suprasystemic right ventricular pressure: echocardiographic observations. Indian Heart J 1998;50:446-50. [PubMed]

4. Faggian G, Frescura C, Thiene G, Bortolotti U, Mazzucco A, Anderson RH. Accessory tricuspid valve tissue causing obstruction of the ventricular septal defect tetralogy of Fallot. Br Heart J 1983;49:324-7. [PubMed] [CrossRef]

5. LaCorte MA, Boxer RA, Singh S, Parnell V Jr, Goldman M. Echocardiographic features of tetralogy of Fallot with an accessory tricuspid valve leaflet. Am Heart J 1985;110:1297-9. [PubMed] [CrossRef]

This work is licensed under the Creative Commons Attribution-NonCommercial-NoDerivs 4.0 Unported (CC BY-NC-ND4.0) License. To view a copy of this license, visit http://creativecommons.org/licenses/by-nc-nd/4.0/ or send a letter to Creative Commons, PO Box 1866, Mountain View, CA 94042, USA.

Publisher's Note: The content of this publication does not necessarily reflect the views or policies of the publisher, nor does any mention of trade names, commercial products, or organizations imply endorsement by the publisher. Scientific and legal responsibilities of published manuscript belong to their author(s). The publisher remains neutral with regard to jurisdictional claims in published maps and institutional affiliations. 